\title{
Influence of Leg Dominance on Single-Leg Stance Performance During Dynamic Conditions: An Investigation into the Validity of Symmetry Hypothesis for Dynamic Postural Control in Healthy Individuals
}

\author{
Dinamik Koșullarda Bacak Baskınlığının Tek Bacak Üzerinde Duruș Üzerine Etkisi: Sağlıkı \\ Bireylerin Dinamik Postüral Kontrollerindeki Simetri Varsayımının Geçerliliği Çalıșması
}

\author{
Mutlu CUĞ ${ }^{1}$, Recep Ali ÖZDEMiR² ${ }^{2}$ Emre AK ${ }^{3}$ \\ ${ }^{1}$ Department of Physical Education and Sports, Cumhuriyet University, Sivas, Turkey \\ ${ }^{2}$ Center for Neuromotor and Biomechanics Research and Department of Health and Human Performance, University of Houston, Houston, TX, USA \\ ${ }^{3}$ Department of Physical Education and Sports, Middle East Technical University, Ankara, Turkey
}

\begin{abstract}
Objective: The primary purpose of the present study was to examine differences in balance performance between the dominant and nondominant legs during dynamic balance tasks in healthy individuals with no regular exercise backgrounds. As a secondary purpose, gender differences in single-leg stance were also investigated.

Material and Methods: Twenty-one men and 24 women participated in this study. Single-leg balance performance was evaluated by the Biodex Stability System SD. All subjects were tested at level 1 for $20 \mathrm{sec}$, and 1 -minute rest intervals were provided among 6 trials for each leg. Results: According to the results, there was no multivariate effect of leg dominance on any stability index, indicating symmetry between limbs in terms of balance performance. Mean comparisons showed that women had significantly better balance scores than men on overall $(p<0.05)$, antero-posterior $(p<0.05)$, and medio-lateral $(p<0.05)$ stability indexes. Conclusion: Functional symmetry exists between the dominant and nondominant leg in all stability indexes of balance performance of sedentary individuals. Female subjects swayed less than males on both the dominant and the nondominant leg measurements in all directions (overall, antero-posterior, and medio-lateral directions).
\end{abstract}

Key Words: Balance, functional symmetry, dominant/nondominant leg, gender differences, biodex balance system
Özet

Amaç: Bu çalışmanın birincil amacı, düzenli egzersiz geçmişine sahip olmayan sağlıklı bireylerin baskın olan ve olmayan bacaklarının dinamik denge performansları arasındaki farkın araştırılmasıdır. Ikincil amaç olarak da, tek ayak üzerinde duruşta cinsiyet farkının araştırılmasıdır.

Gereç ve Yöntemler: Yirmi bir erkek, 24 kadın çalışmaya katılmıştır. Tek ayak performansları Biodeks Denge Sistemi kullanılarak değerlendirilmiştir. Bütün katılımcılar, her bacak için, seviye 1'de, bir dakikalık dinlenme aralarıyla bölünmüş 20 saniyelik 6 deneme yapmışlardır.

Bulgular: Çalışmanın sonuçlarına göre, bacak dominantlığının her 3 denge indeksi üzerine etkisi bulunmamıştır. Bir başka deyişle denge açııından uzuvlar simetrik bulunmuştur. Karşılaştırmalar sonunda kadınların skorları hem toplamda $(p<0,05)$, hem ön-arka dengede $(p<0,05)$, hem de iç-dış denge de $(p<0,05)$ erkeklerden daha iyi bulunmuştur.

Sonuç: Spor yapmayan bireylerin bütün denge indeksi skorları göz önünde bulundurulduğunda baskın olan ve olmayan bacakları arasında fonksiyonel bir simetri söz konusudur. Kadın katılımcılar, hem baskın olan hem de olmayan bacaklarında her denge indeksi için de erkeklerden daha az bir salınım gerçekleştirmişlerdir.

Anahtar Kelimeler: Denge, fonksiyonel simetri, baskın olan ve olmayan bacak, cinsiyet farklılıkları, biodeks denge sistemi 


\section{Introduction}

Optimal control of upright stance requires intact sensory motor functioning. While sensory functioning includes continuous integration of visual, somatosensory, and vestibular afferents to monitor the biomechanical state of the body, motor functioning refers to the ability to initiate corrective neuromuscular responses to retain the body's center of mass (COM) within the base of support (1). Deficiencies in any related sensory (e.g., vision loss, vestibular disorders) or motor system (e.g., lower body injuries) may increase spontaneous body sway and degrade balance performance (2-4).

Ankle and knee injuries dramatically impair functional balance and are some of the most common lower body injuries not only among athletes but also the general population $(5,6)$. The main goal of any successful rehabilitation is to optimize the functional recovery process and achieve the preinjury state of individuals by restoring damaged physical, neurological, and physiological capabilities (7). Under ideal conditions, this requires periodic monitoring of the preinjury state of the person. However, while athletes undergo various performance tests (strength, endurance, stability), there are no regular monitoring practices for sedentary individuals. Thus, clinicians take the uninjured limb into account as a reference to evaluate recovery of the injured limb, assuming functional symmetry exists between limbs at preinjury. Although some previous research has supported limb symmetry by reporting comparable balance performance between the dominant and nondominant legs in healthy subjects (8-11), studies are mostly limited to quiet standing tasks (12).

Many researchers, however, indicated that traditional measures of balance with static tasks are limited in their capability to capture multiple aspects of postural control and thus may not be suitable for monitoring functional improvements in daily life tasks $(13,14)$. Unlike quiet standing conditions, most of the daily life activities are performed in constantly changing environmental contexts and require instant biomechanical adaptations. Dynamic balance tasks, therefore, have been increasingly recommended recently to monitor functional recovery after injury, since they are believed to reflect the underlying mechanism of postural control strategies utilized in daily life activities $(15,16)$. Hatzitaki et al. (17), for example, have shown that balance performance under quiet standing tasks is mostly related to perceiving and processing visual inputs, whereas maintaining balance under dynamically demanding tasks depends highly on rapid processing of somatosensory afferences and initiation of corrective motor responses. They also indicated that under dynamic conditions, the postural control system adapts predictive control strategies (i.e., anticipatory postural adjustments), in which sensory signals from the proprioceptive system need to be processed in a feedforward manner to project expected COM deviations with respect to internal references and external perturbations. This suggests that dynamic postural tasks might be more appropriate to test not only muscular recovery but also position sense recovery (i.e., improvements in the proprioceptive system), since they include proprioceptively demanding conditions.
Although these studies help us to get some insight into the balancing strategies of the postural control system under challenging conditions, unipedal performance differences between dominant and nondominant limbs were not reported clearly for sedentary individuals. Thus, we undertook the present study to examine if postural control performance symmetry exists between the dominant and nondominant legs during dynamic balance tasks in healthy individuals. We believe that the results of this study would have practical implications for designing clinical interventions after injury, since many clinicians rely on measurements of the uninjured limb as a reference to evaluate the recovery process.

\section{Material and Methods}

\section{Subjects}

Twenty-one men and 24 women volunteered to participate in this study. Descriptive characteristics of the subjects are provided in Table 1. Inclusion criteria were set as: 1) having no regular exercise background 6 months prior to the study and 2) being healthy with no diagnosis of any cardiovascular, metabolic, orthopedic, and vestibular disorders. While the General Health Status Questionnaire was used to identify health status, the Exercise Stage of Change Questionnaire-ESOC (18) was employed to determine the physical activity level of the subjects. The validity and reliability of the Turkish version of the ESOC were tested by Cengiz et al. (19). The experimental protocol was approved by the (Middle East Technical University Graduate School of Natural and Applied Sciences No:78-1597) local ethics committee. All subjects signed a consent form after being fully informed of the study's methods, possible side effects, and purpose.

\section{Biodex Stability System}

The Biodex Balance System SD (BSS) (Biodex, Inc., Shirley, NY, USA) was used to measure the dynamic unilateral stability of the subjects. The BSS is designed to induce instability on 360 degrees of circular motion and has the capability to tilt horizontally in all directions up to 20 degrees. Subjects can be tested under 12 different instability levels, where level 1 is the most unstable and level 12 is the most stable condition. The user manual instructions were followed to ensure the quality of measurements. During the testing, subjects can also receive real-time visual feedback, via digital screen, with respect to their COM sway over the platform. Three stability indexes that were derived from the measurements were 1) antero-posterior stability index, 2) medio-lateral stability index, and 3) overall stability index. The lower the index score, the superior the balance performance.

Table 1. Characteristics of participants

\begin{tabular}{lcc}
\hline & $\begin{array}{c}\text { Male }(\text { Mean } \pm \text { SD) } \\
(\mathbf{n = 2 1 )}\end{array}$ & $\begin{array}{c}\text { Female }(\text { Mean } \pm \text { SD) } \\
(\mathbf{n}=\mathbf{2 4})\end{array}$ \\
\hline Height (meter) & $1.78 \pm .07$ & $1.64 \pm .06$ \\
Weight (kilogram) & $73.01 \pm 11.16$ & $59.47 \pm 7.62$ \\
Body Mass Index $\left(\mathrm{kg} / \mathrm{m}^{2}\right)$ & $23.01 \pm 2.54$ & $22.15 \pm 2.17$ \\
Age (years) & $22.14 \pm 2.10$ & $21.33 \pm 1.24$ \\
\hline SNP: single-nucleotide polymorphism; bp: base pair; SD: standart deviation
\end{tabular}




\section{Testing Protocols}

All subjects were tested on single-leg stance conditions while their eyes were open. After taking a comfortable position over the BSS platform barefoot, subjects were asked to keep their arms across their chest and fix their gaze during the trials. They were told that they could flex their testing knees up to 15 degrees. The non-testing leg was kept at 90 degrees of knee flexion and was not allowed to make contact with the testing leg during the measurements. Subjects were allowed to see their COM movements, via the digital screen, while they were being tested (Figures $1 a, b)$. Single-leg dominance was determined by asking them which leg they would use to kick a ball (11). All subjects were tested at level 1 for $20 \mathrm{sec}$, and 1-minute rest intervals were provided among trials. Six successive trials (no falls) were completed for each leg (a total of 12 trials per subject), and the best scores of these trials were recorded as the balance performance of the subject for data analysis. Trials were marked as "fall" if the subject touched the ground with his/her hanging foot or took a step or lost the standing position and touched the side bars of the platform with his/her hands. First, the dominant leg and then the nondominant leg was assessed. All subjects were spotted with the same researcher.

\section{Statistical Analyses}

In order to examine the effects of gender (Factor 1: Male vs Female) and leg dominance (Factor 2: Dominant vs Nondominant) on 3 indicators of balance performance (Dependent Variables: Antero-posterior stability index, Medio-lateral stability index, and Overall stability index), $2 \times 2$ factorial multivariate analysis of variance (MANOVA) was used. Descriptive statistics were used to describe the demographic characteristics of the subjects. Alpha level was set as 0.05 to determine the significance of the results.

\section{Results}

The results of the $2 \times 2$ factorial MANOVA revealed no multivariate effect of leg dominance on any stability index, indicating
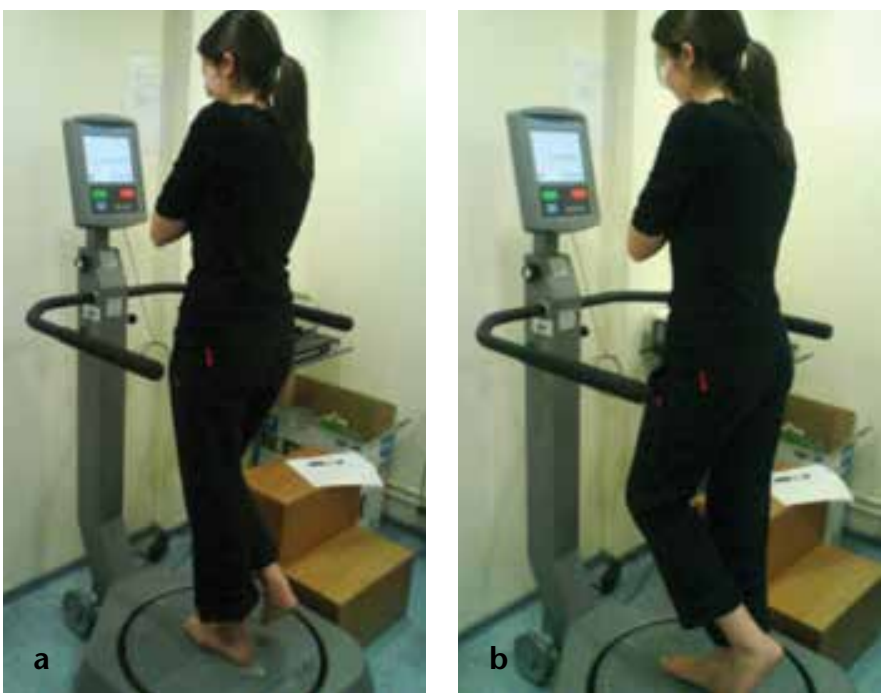

Figures $1 \mathrm{a}, \mathrm{b}$. Testing positions of dominant and nondominant legs symmetry between limbs in terms of balance performance. However, a significant multivariate gender effect was found (Wilks' Lambda $\left.=0.79, \mathrm{~F}_{(3,84)}=7.58, \mathrm{p}=0.00015\right)$ with a large effect size (partial eta-squared $=.98$ ). Follow-up ANOVAs indicated significant gender differences for overall stability index $\left(F_{(3,84)}=7.58\right.$, $\mathrm{p}=0.00015)$, antero-posterior stability index $\left(\mathrm{F}_{(3,84)}=7.58\right.$, $\mathrm{p}=0.00015)$, and medio-lateral stability index $\left(\mathrm{F}_{(3,84)}=7.58\right.$, $\mathrm{p}=0.00015$ ). Mean comparisons showed that women had significantly better balance scores than men on the overall (Women: $\mathrm{M}=1.00$ deg., $\mathrm{SD}=.34$, vs. Men: $\mathrm{M}=1.73$ deg., $\mathrm{SD}=1.00$ ), anteroposterior (Women: $\mathrm{M}=.78$ deg., $S D=.28$, vs. Men: $M=1.32$ deg., $\mathrm{SD}=.73$ ) and medio-lateral (Women: $\mathrm{M}=.55$ deg., $\mathrm{SD}=1.20$, vs. Men; $\mathrm{M}=.97$ deg., $\mathrm{SD}=.59)$ stability indexes. Finally, no significant interaction effect (Gender X Leg dominance) was found on any stability index (Figure 2 ).

\section{Discussion}

The primary purpose of the present study was to examine differences in balance performance between the dominant and nondominant legs during dynamic balance tasks in healthy individuals with no regular exercise backgrounds. As a secondary purpose, gender differences in single-leg stance were also investigated.

The results mainly indicated that a functional symmetry exists between the dominant and nondominant legs in all stability indexes of balance performance. These findings are in line with most of the previous research that examined single-leg stance performance in quiet standing tasks (8-11). Clifford and Power (12), for example, studied postural control differences in 20 healthy subjects, and their results showed that although healthy subjects used different postural control strategy for the functionally dominant leg as compared to the nondominant leg, postural sway was similar between legs in quiet standing tasks. Alonso et al. (20) also investigated the effects of leg dominance on single-leg balance performance in healthy males and found no significant differences between the dominant and nondo-

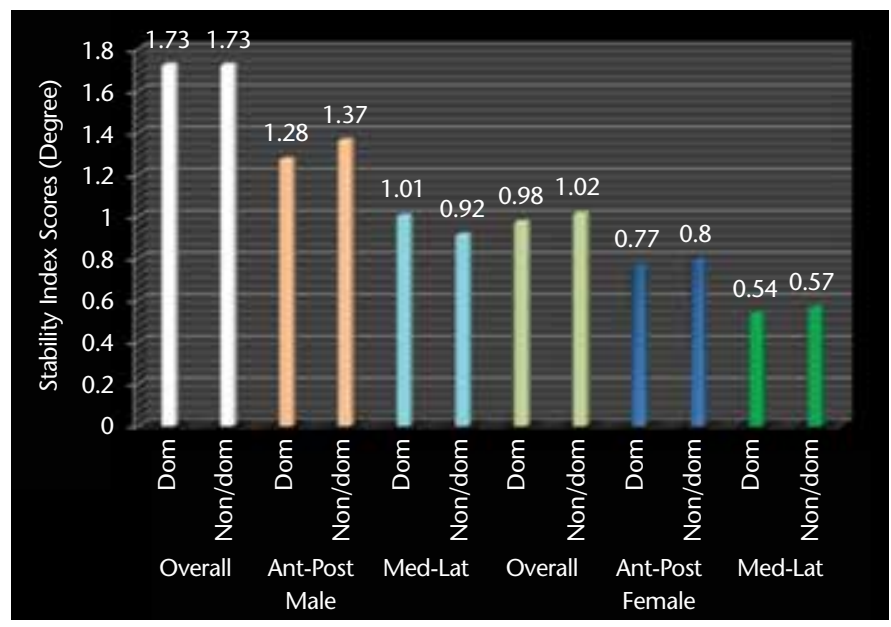

Figure 2. Stability index scores of participants 
minant leg. The present study confirms these previous findings and further indicates that balance performance symmetry also exists for dynamically challenging tasks in healthy women and men. Balance performance symmetries between the dominant and nondominant legs can be attributed to the physical activity patterns of the subjects in this study. For sedentary individuals, daily activities of the lower body mostly include walking, stair climbing, and sit-to-stand movements. During these cyclic movements, it has been well documented that both the dominant and the nondominant legs are used synchronously and, thus, quite possibly contributed the same amount to the generation of movements (21). On the other hand, overuse of one leg over another for certain athletic activities, such as shooting in soccer or kicks in combat sports, develops limb asymmetries in the athletic population. In this regard, Barone and his colleagues (22) found that male soccer players have superior balance performance on their nondominant legs as compared to dominant leg measures in quiet standing tasks. Taken together, these results suggests that clinicians should be careful about relying on limb symmetry when working with different populations and should take preinjury physical activity patterns of the individuals into account while designing restorative therapies.

Another interesting finding in this study is the significant balance performance differences between men and women. The results showed that female subjects swayed less than males on both the dominant and the nondominant leg measurements in all directions (antero-posterior and medio-lateral directions). Previous research is inconclusive with respect to gender differences in postural control performance (23-25). Some studies have reported poorer balance control for men and attributed their results to anatomical disadvantages of men for controlling COM sway. In one of their studies, Farenc et al. (26) pointed out some morphological and physiological disadvantages for men, such that men have a larger moment of body inertia (due to height and weight) and their soleus muscles are also producing more force during quiet stance, all of which are assumed to contribute to larger body sway. Contrary to these results, some studies $(4,27)$ did not report gender-based differences in standing postural control. The reasons for these controversial findings are not immediately apparent. Although our results also revealed larger sway for men than for women, we are not inclined to conclude that women have superior balance than men in single-leg standing conditions. In the light of current literature, we believe that there might be several confounding factors responsible for gender differences in postural control performance. Psychological factors, for example, such as fear of falling or fall anxiety, have been found to be associated with tighter postural control strategies, as reported by reduced peak-to-peak sway and increased mean frequency of COM sway $(28,29)$. Moreover, in some other studies, elderly people and people with Parkinson's disease displayed reduced $(30,31)$ center of pressure, indicating that larger COM sway may not always be related to poor balance. Thus, it might be reasonable to assume that possible fall anxiety differences between men and women may cause women to choose more conscious and preventive postural control strategies than men. Taking these perspectives together, we suggest that the reasons for gender differences in postural control should be carefully examined in future research to identify if they are caused by some morphological and physiological features or by some other confounding psychological factors.

Our findings are limited to a sedentary and healthy population. Our results should not be extrapolated to pathological populations. Our relatively young, sedentary, but fit subject groups may make the findings less generalizable to older, athletic, and/ or more overweight groups.

\section{Conclusion}

The results of this study provide further support that dynamic balance performance will be similar for both limbs in a healthy sedentary population. Clinicians take the uninjured limb into account as a reference to evaluate recovery of the injured limb. Women showed less movement than men on the Biodex Stability System in terms of overall, anterioposterior, and mediolateral stability index scores.

Ethics Committee Approval: Ethics committee approval was received for this study from the ethics committee of Middle East Technical University Graduate School of Natural and Applied Sciences.

Informed Consent: Written informed consent was obtained from patients who participated in this study.

Peer-review: Externally peer-reviewed.

Author Contributions: Concept - M.C., E.A.; Design - M.C., E.A.; Supervision - M.C., E.A., R.A.Ö.; Funding - M.C., E.A.; Materials - M.C., E.A.; Data Collection and/or Processing - M.C., E.A.; Analysis and/or Interpretation - R.A.Ö.; Literature Review M.C., R.A.Ö., E.A.; Writer - R.A.Ö., M.C.; Critical Review - R.A.Ö., M.C.

Acknowledgements: Thanks to Medical Center Physiotherapy Department for allowing us to use the devices needed for this study.

Conflict of Interest: No conflict of interest was declared by the authors.

Financial Disclosure: The authors declared that this study has received no financial support.

Etik Komite Onayı: Bu çalışma için etik komite onayı Orta Doğu Teknik Üniversitesi Fen Bilimleri Enstitüsü’nden alınmıştır.

Hasta Onamı: Yazılı hasta onamı bu çalışmaya katılan hastalardan alınmıştır.

Hakem değerlendirmesi: Dış bağımsız.

Yazar Katkıları: Fikir - M.C., E.A.; Tasarım - M.C., E.A.; Denetleme - M.C., E.A., R.A.Ö.; Kaynaklar - M.C., E.A.; Malzemeler - M.C., E.A.; Veri toplanması ve/veya işlemesi - M.C., E.A.; Analiz ve/veya yorum - R.A.Ö.; Literatür taraması - M.C., R.A.Ö., E.A.; Yazıyı yazan - R.A.Ö., M.C.; Eleştirel İnceleme - R.A.Ö., M.C. 
Teşekkür: Tıp Merkezi Fizyoterapi Bölümü'ne çalışmayı gerçekleştirebilmemiz için gerekli cihazları kullanımımıza sundukları için teşekkür ederiz.

\section{Çıkar Çatışması: Yazarlar çıkar çatışması bildirmemişlerdir.}

Finansal Destek: Yazarlar bu çalışma için finansal destek almadıklarını beyan etmişlerdir.

\section{References}

1. Forth KE, Metter EJ, Paloski WH. Age associated differences in postural equilibrium control: A comparison between EQscore and minimum time to contact (TTCmin). Gait Posture 2007;25:56-62. [CrossRef]

2. Baltaci G, Kohl HW. Does Proprioceptive Training During Knee and Ankle Rehabilitation Improve Outcome? Phys Ther Rev 2003;8:5-16. [CrossRef]

3. Emery CA. Is there a clinical standing balance measurement appropriate for use in sports medicine? A review of the literature. J Sci Med Sport 2003;6:492-504. [CrossRef]

4. Hahn T, Foldspang A, Vestergaard E, Ingemann-Hansen T. Oneleg standing balance and sports activity. Scand J Med Sci Sport 1999;9:15-8. [CrossRef]

5. Barker HB, Beynnon BD, Renström PA. Ankle injury risk factors in sports. Sports Med 1997;23:69-74. [CrossRef]

6. Bjordal JM, Arnoy F, Hannestad B, Strand T. Epidemiology of anterior cruciate ligament injuries in soccer. Am J Sport Med 1997;25:3415. [CrossRef]

7. Knight KL. Guidelines for Rehabilitation of Sports Injuries. Clin Sport Med 1985;4:405-16.

8. Dietz V, Horstmann GA, Berger W. Significance of Proprioceptive Mechanisms in the Regulation of Stance. Prog Brain Res 1989;80:419-23. [CrossRef]

9. Geurts ACH, Nienhuis B, Mulder TW. Intrasubject variability of selected force-platform parameters in the quantification of postural control. Arch Phys Med Rehab 1993;74:1144-50.

10. Goldie PA, Bach TM, Evans OM. Force platform measures for evaluating postural control - reliability and validity. Arch Phys Med Rehab 1989;70:510-7.

11. Hoffman M, Schrader J, Applegate T, Koceja D. Unilateral postural control of the functionally dominant and nondominant extremities of healthy subjects. J Athl Training 1998;33:319-22.

12. Clifford AM, Holder-Powell H. Postural control in healthy individuals. Clin Biomech 2010;25:546-51. [CrossRef]

13. Baier M, Hopf T. Ankle orthoses effect on single-limb standing balance in athletes with functional ankle instability. Arch Phys Med Rehab 1998;79:939-44. [CrossRef]

14. Cachupe W, Wughalter EH. Reliability of biodex balance system measures. Meas Phys Educ Exerc Sci 2001;5:97-108. [CrossRef]

15. Anderson K, Behm DG. The impact of instability resistance training on balance and stability. Sports Med 2005;35:43-53. [CrossRef]
16. Behm DG, Anderson K. The role of instability with resistance training. J Strength Cond Res 2006;20:716-22. [CrossRef]

17. Hatzitaki V, Zisi V, Kollias I, Kloumourtzoglou E. Perceptual-motor contributions to static and dynamic balance control in children. J Motor Behav 2002;34:161-70. [CrossRef]

18. Reed GR, Velicer WF, Prochaska JO, Rossi JS, Marcus BH. What makes a good staging algorithm: Examples from regular exercise. Am I Health Promot 1997;12:57-66. [CrossRef]

19. Cengiz C, Ince L, Cicek S. Exercise stages of change in Turkish University students by sex, residence, and department. Percept Motor Skill 2009;108:411-21. [CrossRef]

20. Alonso AC, Brech GC, Bourquin AM, Greve JMD. The influence of lower-limb dominance on postural balance. Sao Paulo Med I 2011;129:410-3.

21. Maupas E, Paysant J, Datie AM, Martinet N, Andre JM. Functional asymmetries of the lower limbs. A comparison between clinical assessment of laterality, isokinetic evaluation and electrogoniometric monitoring of knees during walking. Gait Posture 2002;16:304-12. [CrossRef]

22. Barone R, Macaluso F, Traina M, Leonardi V, Farina F, Felice VD. Soccer players have a better standing balance in nondominant onelegged stance. J Sport Med 2010;2:1-6.

23. Black FO, Wall C, Rockette HE, Kitch, R. Normal Subject Postural Sway during the Romberg Test. Am J Otolaryng 1982;3:309-18. [CrossRef]

24. Hageman PA, Leibowitz JM, Blanke D. Age and gender effects on postural control measures. Arch Phys Med Rehab 1995;76:961-5. [CrossRef]

25. Peeters H, Breslau E, Mol J, Caberg H. Analysis of Posturographic Measurements on Children. Med Biol Eng Comput 1984;22:317. 21. [CrossRef]

26. Farenc I, Rougier P, Berger L. The influence of gender and body characteristics on upright stance. Ann Hum Biol 2003;30:279-94. [CrossRef]

27. Ekdahl C, Jarnlo GB, Andersson SI. Standing balance in healthy-subjects-evaluation of a quantitative test battery on a force platform. Scand J Rehabil Med 1989;21:187-95.

28. Brown LA, Polych MA, Doan JB. The effect of anxiety on the regulation of upright standing among younger and older adults. Gait Posture 2006;24:397-405. [CrossRef]

29. Hauck LJ, Carpenter MG, Frank JS. Task-specific measures of balance efficacy, anxiety and stability and their relationship to clinical balance performance. Gait Posture 2008;27:676-77. [CrossRef]

30. Panzer MA, Hallett M. Biomechanical assessments of upright stance in Parkinson's Disease: A single-subject study. Clin Biomech 1990;2:73-80. [CrossRef]

31. Panzer VP, Bandinelli S, Hallett M. Biomechanical assessment of quiet standing and changes associated with aging. Arch Phys Med Rehabil 1995;76:151-7. [CrossRef] 